\title{
CHALLENGES FOR CONSERVATION OF SULAWESI CRESTED BLACK MACAQUE (Macaca nigra)
}

\author{
Tantangan-tantangan dalam Konservasi Kera Jambul Hitam Sulawesi (Macaca nigra) \\ Risma Illa Maulany
}

\begin{abstract}
ABSTRAK
Macaca nigra (kera jambul hitam) adalah salah satu satwa endemik di Pulau Sulawesi yang populasinya di alam semakin berkurang. Menurunnya populasi satwa ini utamanya disebabkan oleh meningkatnya populasi penduduk yang secara tidak langsung mempengaruhi tingkat perburuan satwa ini, yang umumnya dikonsumsi sebagai makanan tradisional masyarakat setempat. Perburuan ini dilakukan semata-mata hanya untuk tujuan komersial. Akses jalan Trans-Sulawesi yang semakin baik juga telah membuka peluang yang lebih besar bagi para pemburu dan pedagang dalam melakukan perdagangan satwa liar. Selain itu, status kawasan, lemahnya penegakan hukum, minimnya sumberdaya manusia pengelola kawasan, dan lemahnya manajemen kawasan serta aktivitas wisata yang tidak bertanggung jawab juga turut berperan dalam menurunnya populasi kera jambul hitam. Tulisan ini mencoba untuk mengetengahkan isu-isu yang mempengaruhi populasi $M$. nigra di alam dan mengidentifikasi tantangantantangan yang harus dihadapi dalam konservasi satwa ini. Rekomendasi untuk mempertahankan populasi dan melestarikan satwa ini juga dibahas dalam tulisan ini.
\end{abstract}

Key words: wild meat, wildlife trade, wildlife tourism, north sulawesi

\section{INTRODUCTION}

The flora and fauna of Sulawesi have been well documented with studies dating back to the $19^{\text {th }}$ century by naturalists such as Wallace (1869), Guillemard (1886), Hickson (1889) and (Lee, 1999). Vertebrate endemism is an outstanding feature of Sulawesi (Bynum et al., 1999) as a result of its geological history and degree of isolation from surrounding islands (Whitten et al., 1987 as cited in O' Brien and Kinnaird, 2000). There are some endemic species of this island such as babirusa (Babyrousa babyrussa), anoa (Bubalus depressicornis), bear cuscus (Ailurops ursinus), dwarf cuscus (Stigocuscus celebensis), redknobbed hornbill (Rhyticeros cassidix), maleo bird (Macrocephalon maleo) and including 7 sulawesi macaques.

Sulawesi crested black macaque (Macaca nigra) is one of the endemic species inhabiting the North Sulawesi area. This species is one of 7 sulawesi macaques that also threatened by human impacts on their populations caused by habitat loss and wildlife trade. Hunting for wild meat consumption by local Minahasans has become one of major causes of this species' population decline.
This paper tries to explore the major issues affecting the $M$. nigra population in the wild and identify challenges in conserving the species. Future recommendations to maintain the populations and preserve the species are also discussed.

The area of study in this paper is North Sulawesi province. From socio-culture aspects, unlike other Indonesian provinces, in North Sulawesi the majority of its people are Christians (approximately $51 \%$ ) which was introduced by Portuguese merchants in the 1500s, followed by Islam, Hinduism, and Buddhism (Lee, 1999; PATA, 2004). There are fewer religious laws against eating wild animals in Christianity than in Islam, so mainly the Christian people of North Sulawesi regularly consume meat of wild animals, particularly during the festive season such as Christmas and post-harvest celebrations (Lee, 1999). This occurs particularly in Minahasa District where $95 \%$ of its populations are Christians (Milner-Gulland and Clayton, 2002). Wild meat is very popular in this districts compared to other districts in North Sulawesi.

North Sulawesi is relatively well-developed (Lee, 1999), largely due to its historical background. European presence in the past -first 
by Portuguese missionaries in the 1560s followed by Dutch settlement - has influenced the local way of life and institutions and practices (Lee, 1999). Well-developed market and road systems are one of the examples of economic development which have enhanced human populations in the area. In turn, there is no doubt, these have indirectly opened an access to exploit the natural resources in the area and put a great pressure on wildlife populations. Moreover, the tradition of eating wild animals has also contributed to the decline of wildlife populations.

\section{MAJOR ISSUES IN M. NIGRA CONSERVATION}

In general, habitat fragmentation and land conversion have also affected primate species in Indonesia. Like most mammals, the main causes of the declining populations of primates are the lost of habitat and fragmentation. Hunting activities for different purposes such as food, sports, and trade have put more pressures for the primate survival. Ineffective management of protected areas and law enforcement have also contributed to this matter (Bynum et al. 1999, Alvard, 2000; Lee, 2000; Clayton and Milner-Gulland, 2000). Moreover, if $M$. nigra found in Bacan Island are proven to be genetically different with their relatives in main land of Sulawesi then they could not be treated as a reservoir of $M$. nigra in the main land and they have to be considered as different population.

\section{Hunting Threats}

\section{Hunting Pressures, motives, and Local Market Demands}

Different areas may present different pressures to wildlife populations. Some are exploited for international trade for pets and ornaments (TRAFFIC, 1993 in Lee, 1999), domestic trade for pets and parts (Wijaya and Ramono, 1991; Edwards and Jenkins, 1993 in Lee, 1999); medicine (Plowden and Bowles, 1997 in Lee, 1999) and crop protection (Pramono et al., 1992; Bynum et al., 1999).

M. nigra is a hunting target in North Sulawesi, particularly for their meat for cultural or traditional ceremonies such as Christmas and postharvest celebrations (Lee, 1999). Hunting in the area is considered cheap and efficient way to obtain food and instant income (Lee, 1999). The hunters usually use traps and snares for small mammals and nets for bats. These methods require little financial output and energy. As mentioned above, this practice has decreased the populations over the years and has led the species near to extinction.

One of the motives behind the high rate of hunting is because meat is a staple of the local peoples' diet (Lee, 1999). According to Centre of Statistics Bureau (Biro Pusat Statistik---BPS, 1994 in Lee, 2000), North Sulawesi has the highest meat consumption rate in the country particularly for pig consumption (Milner-Gulland and Clayton, 2002). In addition, some people prefer to seek wild meat due to its scarcity and unique qualities. As an example, people like to consume macaque meat for its desirable taste, and it is also thought to cure certain ailments (Lee, 1999).

Unlike other places in the region where wild meat consumption is related with rural poverty, most evidence has shown that North Sulawesi is not impoverished (Lee, 2000). This is supported by the data provided by the BPS (1984, 1986 in Lee, 2000) which indicate that North Sulawesi is a province with the high-growth and high-income. This is also supported by various indicators used to identify poverty in Indonesia such as literacy rate, availability of roads, annual income, gross domestic product, and calorie intake. Protein intake per capita in this area is also increased over the 10 year period from 1981 (see Figure 1).

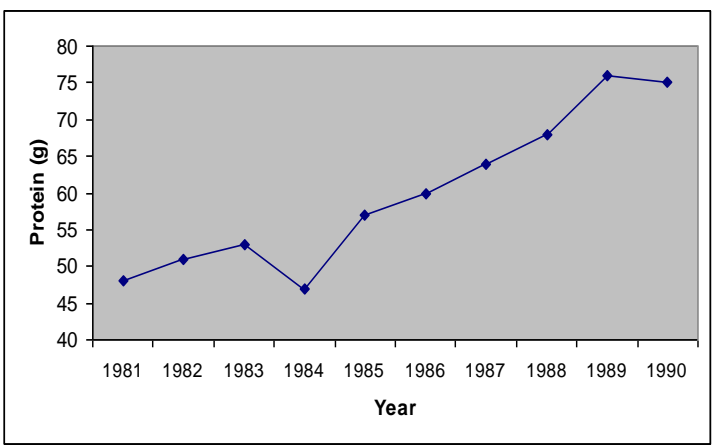

Figure 1. Protein intake per capita per day in North Sulawesi 1981-1990 (Source: Kantor Statistik Propinsi Sulawesi Utara (KSPU), 1988,1990,1992 in Lee, 2000)

From the BPS, it is also known that this province had the eighth lowest incidence of rural poverty among all Indonesian provinces, with only $11.4 \%$ of its population below the poverty line (Booth, 1998 in Lee, 2000). This, once again 
shows that one of the reasons behind wild meat consumption in the North Sulawesi is culture and tradition based which have been enhanced by human population growth.

The tradition of consuming wildlife meat such as wild pig, bats, rodents, and protected species such as dwarf cuscus, bear cuscus, Heck's macaque, Gorontalo macaque, crested black macaque, anoa, rusa deer and babirusa, is a strong part of the culture of local people of North Sulawesi (Lee, 1999). Lee (1999) in his study on market and hunting pressures on wildlife populations in Manembonembo area has found that in the local markets all wild meats sold consisted of murid rodents $(49 \%)$, bats (31\%), Sulawesi wild pig (19\%), and protected species (1\%). There were 29 species in all.

The meats sold in the market generated from protected species in general, are dominated by dwarf cuscus. Macaque is the second largest most consumed species in the market followed by babirusa, bear cuscus, rusa, and anoa.

\section{Hunting and Market Location}

As explained above, almost all M. nigra are found in the protected areas of North Sulawesi. Therefore, the intensity of hunting on this species is largely concentrated in protected areas such as in Tangkoko-Batuangus Duasaudara Nature Reserve, Manembonembo Nature Reserve, and Gunung Ambang Nature Reserve (Lee, 1995 as cited in Lee, 1999). It is also found that snares and traps are common in these protected areas.

Hunting activity is geographically limited (Lee, 1999). Small-bodied mammals are caught mostly in local areas whereas large-bodied mammals are usually caught in the western of North Sulawesi and central Sulawesi (Lee, 1999). Hence, the establishment of Trans-Sulawesi Highway has bridged and enhanced the decline or the loss of wildlife populations, particularly $M$. nigra (MilnerGulland and Clayton, 2002).

Wild meat is usually sold in local markets in Minahasa; Langowan, Tomohon, and Kawangkoan (Lee, 1999). M. nigra are caught by local people near the forests, then their meat smoked and taken to the market town to sell to a market trader (Clayton and Milner-Gulland, 2000). Even though the number that is sold is relatively low, there are 515 monkeys per month in each town (Tomohon and Langowan) (Milner-Gulland and Clayton, 2002). Prior to Christmas, the number increases to 20 monkeys per one dealer (Clayton and MilnerGulland, 2000).

There are no available data explaining other local uses (such as for pets, ornaments, accesories, etc.) of $M$. nigra outside for meat consumption. However, other wild animals are occasionally found on the streets of Manado (the capital city of North Sulawesi). Wildlife products such as feathers from hornbills, reptile skins, deer antlers, and babirusa tusks are traded amongst villagers and have little market value compared to the wild meat trade (Lee, 1999).

International trade on $M$. nigra also occurs not only for meat pets and body parts. It was reported by Waldman (2004) that particularly infants, were exported. These babies of $M$. nigra were sent to Taiwan where then there, by using sharp bamboo sticks, the Taiwanese puncture the babies soft skulls and eat the raw brains. This activity could provide instant cash and better prices where one individual of $M$. nigra is valued tripled from local prices. Little commercial use of animals beside for meat consumption is found in North Sulawesi (Lee, 1999).

\section{M. nigra as a tourism object in Protected Areas}

Indonesia, like many other developing countries, is changing to ecotourism in an attempt to integrate the goals of development and nature conservation (Kinnaird and O'Brien, 1996). $M$. nigra has become an object of tourism in some protected areas in North Sulawesi. Kinnaird and O'Brien (1996) evaluated ecotourism practices in Tangkoko-Batuangus-DuaSudara Nature Reserve by examining trends in visitor numbers, the tourist experience, the distribution of tourist revenue, and tourist impact on the Sulawesi black macaque and spectral tarsier (Tarsier spectrum).

Foreign tourists visiting North Sulawesi are increasing annually at $30 \%$ (Natural Resources Management Project-NRMP, 1993) and this has influenced an increase of tourism to TBDS Nature Reserve. In addition, prior to the recent economic and political crises, the province of North Sulawesi has gained $\pm 330,000$ tourists annually $(30,285$ of which were international). This shows a threefold increase in total visitors visiting the province in 1990 (Dinas Pariwisata, 1996 as cited in Ross and Wall, 2001). 
Primate behavior is being affected by tourists who visited the area (Kinnaird and O'Brien, 1996). During their studies, 3 groups of $M$. nigra approached by some tourists have shown different actions such as group splitting, climbing/running to the tree, and screaming. Tourist behavior such as feeding the animals will indirectly affect the behavior of these animals to become more aggressive. In addition, the time spent by macaques for foraging and feeding could be seriously reduced due to wildlife viewing (Kinnaird and O'Brien, 1998). Moreover, local benefits derived from tourism are not being fully realized and the reserve does not generate enough money to implement management (Kinnaird and O'Brien, 1996).

\section{Socio-economic benefits of tourism}

The number of tourists visiting the reserve is increasing from year to year, however, most of them only spend a few hours, entering the reserve at dusk or dawn to view wildlife. Not many of them were willing to stay overnight. The shortest stay inside the reserve was only 2 hours after seeing their main objective such as spectral tarsier and crested black macaque. Therefore, from a sociocultural context, there is only little contact made between tourists and local villagers.

In relation with economic importance derived from tourism to local people, only a few local residents near the reserve currently benefit from tourism (Ross and Wall, 2001) and mostly by providing accommodation (homestays) near the reserve entrance. The homestays are usually owned by reserve staff (wardens) (Kinnaird and O'Brien, 1996). These homestays do not generate income both to the reserve and the wider community at local people.

Guided tours may become an opportunity for the local to gain benefit. Meantime, most guided tours that are allowed to enter the reserve are a monopoly of reserve staff or tour companies from Manado (Kinnaird and O'Brien, 1996; Ross and Wall, 1999). If this occurs continuously, there is no doubt that in future, the conflict related with wildlife uses between local people and reserve management will arise.

Another impediment to tourism in protected areas in North Sulawesi is tourist expenditures which are limited by the lack of items available for purchase (Ross and Wall, 2001). There are no shops, homestays, restaurants, or other additional value attraction inside the village near the reserve where the tourists could spend more time and money after or before observing wildlife.

Only a small proportion of tourism revenues are going to the reserve for wildlife protection and management (Kinnaird and O'Brien, 1996). The entrance fee to the reserve is very cheap - only Rp 750,- (AU\$ 12 cents) and it all must be remitted to the central government (BAPENAS/NRMP/USAID, 1993 in Ross and Wall, 1999).

The impact of tourism inside the reserve should also be monitored. For example, in early July 1995 two new homestays were established inside the reserve to accommodate peak season tourists, and this has earned some income that could possibly go to the management of the reserve. On the other hand, it has also increased vehicle and pedestrian activity in places that are currently part of the territory of crested black macaque (Ross and Wall, 2001).

\section{Status of the reserve}

The status of TBDS as a nature reserve based on Indonesian wildlife law restricts any activities except for research and education conducted inside the protected area, including tourism. Therefore, tourism is viewed as an illegal action. For $M$. nigra, it is obvious that the presence of tourists has negatively affected behavior. It has been shown by Kinnaird and O'Brien (1998) that most of the animals were disturbed as shown by group splits, running or screaming, climbing trees when tourist approached (Kinnaird and O'Brien, 199).

The increase of tourist numbers viewing $M$. nigra indirectly has increased stresses on the animals. Moreover, time spent by macaques foraging and feeding could be seriously reduced (Kinnaird and O'Brien, 1996). Tourist behavior such as feeding the animals will indirectly affect the behavior of these animals which may become more aggressive.

The imbalanced flows of socio-economic factors will trigger conflicts between people and protected areas. Moreover, unsuccessful 'policing' efforts by authorities within the protected areas, and decision making (such as park boundary and establishment of use zones) that has occurred without involving the locals, can lead to confusion and anger. This will again, put 
more pressures for wildlife population (Ross and Wall, 1999).

\section{Weak Law Enforcement}

The protection of wild plants and animals in Indonesia is achieved under the Conservation of Natural Resources and Ecosystems Act (No. 5) of 1990 (Republik Indonesia 1990). The law emphasizes protection of flora and fauna, unique ecosystems, the use of conservation areas, as well as prescribing penalties for offenders. This law protects 545 fauna species including 94 mammals (Clayton and Milner-Gulland, 2000). It also prohibits catching, trading (alive or dead), or killing a protected species as well as the possession or trading in parts of any protected species (Clayton and Milner-Gulland, 2000; Deptan, 2004). The penalty for infringement of this regulation is a maximum 5 years in prison and a maximum fine of Rp 1,00,000,000 (AU\$ 16,700).

The law also establishes the status of protected areas including nature reserves. In nature reserves, it is forbidden to conduct any kind of activity inside the reserve except for research and education. Therefore, hunting and tourism activities inside are strictly prohibited. In reality, those practices are happening and growing (shown by the increase of numbers of hunters, dealers, wild meats sold in the markets, and tourists in the areas). As explained by Lee (1999), patrolling by the rangers around the protected areas is rare, as are patrols in the markets that sell meat of protected species. Moreover, Clayton and Milner-Gulland (2000) add that the enforcement of the law is still weak. As an example, in September 1989, the local police intercepted two Minahasan dealers' vehicles in the Gorontalo district, which were being loaded with 17 babirusa and two anoa. Then, the meat was taken away by the officers after explaining the wildlife law against poaching to the hunters but there was no further action taken.

\section{Habitat Loss}

The population in North Sulawesi is expanding from year to year. According to the BPS (2004) there was an average $15 \%$ increase of human population in North Sulawesi from 1990 to 2000. This has enhanced land conversions in many areas for development and reduced the habitat of wildlife in general, and may contribute to the decline of the populations of $M$. nigra. As the populations of humans increased, many agricultural lands were established by land clearing, opening forested areas and reducing the habitat of this species. Based on 1990 statistics, close to $60 \%$ of the land in North Bitung District has already been appropriated for agricultural uses, primarily plantations (Karwur et al., 1994 in Ross and Wall, 2001).

According to Ross and Wall (2001), twothirds of people living in close proximity to the Tangkoko-DuaSudara Nature Reserve depend on agriculture, including crops, plantations, and livestock.

In turn, crop raiding by macaques has become more frequent, particularly in agricultural land near the forest. To protect yields, hunting or trapping the animals surrounding the field by the farmers has become common activity to also generate extra income. Indirectly, this activity has enhanced the decline populations of macaques.

It has been shown that some populations of primates still may use forests disturbed by from logging activities (Johns and Skorupa, 1987). However, the level survival varies between species and individuals. In addition, habitat quality is also an important factor in maintaining and supporting a healthy population. Disturbed forests may still act as a habitat, but its quality in general is reduced. Therefore, even in Indonesia where selective logging has been applied the ecosystem can not provide sufficient and optimal sources for wildlife populations (FWI/GWF, 2001). Moreover, this activity has opened the gate for outsiders to access the resources.

In the case of $M$. nigra, opening land for establishing roads has also become a cause of wildlife depletion in the area. The Trans-Sulawesi highway has enhanced the accessibility and mobility of the hunters to obtain more benefit from wildlife hunting and trade. Specific to Tangkoko, agricultural activities and livestock grazing to the area and illegal overharvesting of forest flora such as the palm (for roof making) and others, have put more pressures on wildlife populations.

There are no data available on current habitat quality assessment in places where $M$. nigra occurs as well as the impact of any development (such as land opening, road establishment, etc) in areas surrounding to their habitat. 


\section{Genetic Reservoir for M. nigra in Bacan Island}

There was a controversial argument drawn by some scientists related with the population sustainability of $M$. nigra. They believe that $M$. nigra populations on Bacan Island can act as a reservoir of $M$. nigra populations on main island of Sulawesi that are experiencing a decrease. According to Hamada and Watanabe (1994), M. nigra on Bacan island is similar to the populations in North Sulawesi. They only used morphological inspection (by identifying its characters and applied line transect census method to survey the animals number complied by interviews with the villagers to ensure the presence of the monkey) to conclude that the M. nigra on Bacan is similar with the one at the main island. There was no attempt by Hamada and Watanabe to determine whether the species on Bacan are genetically the same as those on the mainland. Rosenbaum (1997 in Lee, 1999) also noted that there is no morphological or ecological difference between $M$. nigra in these two areas.

Froehlich et al. (1996) examine foot fingerprints patterns of Macaques by using a nested canonical analysis. They argue that the Bacan $M$. nigra is lacking in genetic variation. It was proved by their results from fingerprint canonical display, shown that Bacan was totally separated with others. They emphasize that it is not the representative of $M$. nigra as a whole and is not an appropriate conservation reservoir or restocking source for the species.

Even it is known that the population density in Bacan is larger and healthier than in the mainland, and the hunting pressures in the island are lesser.

\section{Present Conservation and Management}

In Indonesia, a number of methods of controlling illegal trade and sale have been endorsed over the years (Lee, 1999). M. nigra is protected under the law, the Conservation of Natural Resources and Ecosystems Act (No. 5) of 1990 (Republik Indonesia 1990), government regulations hunting (No. 13) and Utilization of Conservation Areas (No. 18). These regulations provide guidelines for the exploitation of protected animals and use of protected areas (Lee, 1999). Yet, full implementation of this law is still lacking. Findings from several studies in the areas indicate that these regulations are routinely violated (Kinnaird and O'Brien, 1996; Bynum et al., 1999;
Lee, 1999; Alvard, 2000; Clayton and MilnerGulland, 2000; O'Brien and Kinnaird, 2000; Milner-Gulland and Clayton, 2002). While the content of the regulations has provided enough protection for wildlife and protected areas, these are not accompanied by enforcement of the law and are not supported by sufficient human resources. As an example, patrolling does not take place in most protected areas and markets where wild meats are sold (Lee, 1999). Entry gate, border lines and check points in major roads are rarely patrolled (Lee, 1999), giving opportunity for offenders to enter the areas and transport the animals without any difficulties.

Moreover, individuals that have been caught for infringing wildlife protection laws have rarely been sentenced (Lee, 1999). This points out the weakness of the judicial system. If a person were to be convicted of violating the laws and was fined the maximum penalty of AU\$ $16,700(\operatorname{Rp} 100,000,000)$, it is almost certain that there will be no way for this person to pay that large amount of money. This is particularly so for small hunters who could only earn approximately AU\$ 25 (Rp 150.000) from 15 monkeys in 2-6 months. In general, they are seldom prosecuted to the full extent of the law (Lee, 1999).

Another important point is human resources involved in protecting wildlife and protected areas. Lack of training and facilities for field officers is one of the major problems in the wildlife trade. Many officers (usually forestry guards or police officers) are not familiar with the species that are allowed or not allowed to be traded (Lee, 1999). Variation in wildlife products sold in the international market such as parts, products or derivative of a specimen, has made the capacity of an officer to identify it even more complex and demanding (Young, 2002). In addition, Lee (1999) mentions an example of untrained officers who wanted to release in Tangkoko Nature Reserve a confiscated green python (Morelia viridis) from the Moluccas (Maluku) which was not native to Sulawesi (O'Brien, pers.com.).

Furthermore, there are insufficient personnel and facilities to support their activities in protecting the resources. For example, in Manembonembo Nature Reserve, there were only four to six guards responsible for management of the reserve and they rarely entered the reserves (Lee, 2000). On the other hand, the officers working in the field are not 
supported by a regional and national infrastructure that adequately supervises job performance, pays living wages, rewards protection and enforcement milestones, and provides appropriate training and advancement (Bynum et al., 1999).

The status of nature reserve under the laws of North Sulawesi does not allow any activities (except for research and educational purposes) and management such as zoning areas and other types of management inside the areas.

\section{CHALLENGES FOR CONSERVATION OF M. NIGRA}

From several points discussed above, it is clear that there are many complex challenges need to be addressed if the conservation of $M$. nigra is to be achieved.

\section{Biological and ecological aspects of M. nigra}

Firstly, it has to be realized that information to fully assess the conservation status and needs of $M$. nigra is still lacking. It is true that several studies on this species have been conducted, but most of the studies were focused only on surveys of population status and distribution (Rosenbaum et al., 1998; Hamada and Watanabe, 1994; Lee, 1999; Sugardjito et al., 1989 in O'Brien and Kinnaird, 1997); and few ecological and behavioral studies have been conducted on wild populations (Thierry et al., 1994 as cited in O'Brien and Kinnaird, 1997). Therefore, there is a need to explore in depth the biology and ecology of $M$. nigra to provide better protection for this species and its habitats, particularly in seven different places where this species occurs. In the future, further research aspects below should be taken into account:

1. Comprehensive survey on current populations and distribution covering all areas where this species occurs

2. More understanding through behavioral studies on wild populations

3. More research on $M$. nigra reproduction system to prevent and control hybridization with other species of Macaque

4. Ecological studies to understand the species habitat preferences and needs, the relative abundance of the species and their ability to persist largely or exclusively in highland areas (Bynum et al., 1999)
5. Habitat quality assessment in all protected areas where the species inhabits (conduct a survey to identify important food sources and their distribution in all areas). A study on fig tree distribution has been conducted by Kinnaird et al. (1999) only in Tangkoko area.

6. Recommend protection for important food sources vegetation (such as fig trees) as those are considered important to affect the populations, distributions, movement, and behavioral patterns of $M$. nigra.

7. Increase the awareness that populations of M. nigra in Bacan Island is not a replacement or reservoir of $M$. nigra on the mainland of Sulawesi and conduct further research genetic characteristics at Bacan Island and mainland populations.

\section{Wildlife law enforcement and human resources improvement}

It has been realized that effective wildlife protection must go hand in hand with legislation and law enforcement. In the case of $M$. nigra conservation in North Sulawesi, this has not been fully achieved and mostly not supported by human resources involved in this area. In order to enhance law enforcement the following steps should be noted.

1. Enforcement of existing Indonesian laws prohibiting hunting, agriculture and other extractive activities in protected areas (Bynum et al., 1999)

2. Enforcement of existing regulations including confiscation of poached animals and forest products and prosecution of violators (Bynum et al., 1999)

3. Increase awareness of the staff and field officers of the importance of law enforcement

4. Regular provision and monitoring ofjob performance by high level management (Directorate General for Nature Conservation and Forest Protection) to the staff and field officers of the reserve.

5. Priority to regular monitoring and patrolling along the reserve and provincial boundaries, entrance gate, check points, and local markets (Lee, 1999)

6. Increase the quality and quantity of personnel in the field supported by regional and national infrastructure and facilities including wages and vehicles (Bynum et al., 1999) 
7. Provide regular training and advancement on wildlife conservation and protection (e.g. training on species identification, alive or dead and the products derived from the specimen)

8. Enlightening the local people by increasing the awareness of the status of the reserve, the importance of wildlife conservation and familiarize the wildlife law in the community (e.g. providing conservation education in schools and community)

\section{Culture and Wild meat Consumption}

The tradition of eating wild meat in North Sulawesi particularly by Minahasan people has contributed to the vast decline of wildlife populations in the area. It has been known that hunting wildlife in this area is not related with food security; It is purely for commercial use and tradition purposes only. Therefore, the local people must be reminded that this cultural practice can no longer be supported. Some steps can be taken in tackling this problem such as:

1. Increase the awareness of the importance of wildlife species and the sense of responsibility toward protecting their wildlife for the future by modifying eating habits and begin monitoring their use of natural resources (Lee, 1999). This can be done through intensive approaches to all level of community structure by involving not only local/traditional leaders but also local religious leaders.

2. Setting quota of how many animals can be consumed. This can be arranged by cooperation with the head of the villages, local government, religious leaders, and the whole community; With an intensive and persuasive approach along with the increase of the availability of other cheaper meat will provide alternatives in meat consumption by local people. Focusing the low quota of wild meat use only for traditional or other certain festive occasions will optimize the use of low quota of wild meat. This will probably direct the perspectives of the local toward the wild meat use (change the awareness that wild meat only for special/big traditional events not for daily consumption).

3. Find alternative food resources and promote intensive farming livestock or other forms of domestic protein sources. As a counter argument for people who consume wild animals (particularly $M$. nigra) for its sensational taste, goat meat or domestic cat can produce the same physical effect (Lee, 1999).

4. Promote cheaper meat sources from domestic protein sources or farming livestock through forming village cooperatives for small-scale farming of domesticated animals (e.g. chickens, cows, pigs).

5. Increase the availability of meat through livestock production and increased harvests of vertebrate pests (Lee, 1999).

6. Increase production of pigs and rodents through subsidized program would provide a steady and inexpensive way to reduce the present rate of wildlife harvesting (Lee, 1999).

\section{Tourism, Wildlife Protection and Protected Areas}

Tourism is another use of wildlife that could generate profits. It has become one solution in integrating development and conservation. However, if this is not supported by careful management, tourism will function as a sink for wildlife populations.

In the case of $M$. nigra, wildlife tourism has not yet provided sufficient protection for the species. There is evidence that the money generated by ecotourism does not necessarily go towards maintaining biological diversity (Kinnaird and O'Brien, 1996). Moreover, current tourism practice in Tangkoko has shown that there is a monopoly by outsiders and reserve staff. This in turn, inevitably will produce more conflicts between local people and protected areas as well as with outsiders.

There are many complex problems involved such as violation of the status of the reserve which forbid tourism in the area, law enforcement, the generation and distribution of profits. Therefore, further steps need to be taken in order to protect and maintain the contribution of wildlife to tourism in this province, such as;

1. Change the status of protected areas to a wider context such as national park will allow to some extent the use of protected areas through zonation, provide greater participation by the local community and secure increased revenues for management. A possible constraint to this recommendation is the small size of most nature reserves in North Sulawesi; most Indonesian National 
Parks are greater than 20,000 ha. However, the concept of sister park to the larger nearby park could bridge this problem. For an example, Tangkoko could be a part of Bunaken Marine National Park as it is located nearby the reserve (Kinnaird and O'Brien, 1996).

2. Change of the status of the reserve, followed by the preparation of master management plan (Kinnaird and O'Brien, 1996)

3. Familiarize the bottom-up approach to incorporate local communities in the development of management plan (Kinnaird and O'Brien, 1996)

4. Increase entrance fees and establish dual payment system for the entrance fee to the reserve; domestic tourists pay a domestic rate (rupiah) and international tourists pay a US dollar rate (converted to rupiah).

5. Establish an extra fee (donation) for conservation for the tourists enter the reserve

6. Establish a clear revenue distribution system among all stakeholders

7. Invite big investors to invest in the establishment of small scale business in villages close to the reserve (such as shops, restaurants, homestays)

8. Promote funding for the establishment of small scale business in some villages close to the reserve.

9. Invite NGOs or local government training centres to provide training such as language, traditional handicrafts, traditional food making, etc to support tourism activities

\section{CONCLUSION}

The rapid increase of human population followed by the increase of hunting pressures in North Sulawesi have largely contributed to the decline of wildlife population particularly Sulawesi crested black macaque ( $M$. nigra). Traditional consumption of wild meat in this area is one of the major causes. Hunting in this area is purely commercial and there is no relationship with food security or traditional hunting for food.

M. nigra as well as other primates has a slow reproductive rate that is susceptible to local depletion. Therefore, overhunting may cause this species to decline to a rapid extinction. Along with the increase of human population, access to markets can affect the hunting rates. Road improvement and the opening of the Trans-
Sulawesi highway have opened wider access for hunters and dealers to sell more animals which could lead to overharvesting practice.

The interest in wildlife viewing in North Sulawesi has put more pressures to wildlife population particularly $M$. nigra, as one of the tourism attractions of the reserves. It has been proved that this activity has disturbed and affected wildlife behavior. Moreover, there is very little revenue for wildlife protection flowing from this activity. There are few opportunities for local people to generate extra income.

The status of the reserve, which restricts any kind of activities including tourism except for research and educational purposes, has put more pressure on wildlife population in this area. Human resources involved in management of the reserve are also contributed to the decline of wildlife populations in the areas such as law enforcement, lack of patrolling activities in vital points and markets, lack of surveillance and monitoring on job performance. Moreover, this is not supported by sufficient personnel and facilities.

Therefore, there is an urgent need to change the situations by filling some gaps in many areas such as to explore more biological and ecological aspects of $M$. nigra, wildlife law enforcement and human resources improvement, change eating habits of local people in consuming wild meat and provide alternative food sources, change the status of protected areas, establish master plan for management plan and promote responsible tourism.

As more information and further steps taken to fill the gaps, it is hoped that wildlife conservation and development can go along together. Even it has been realized that there will always be impacts to natural system, minimizing these impacts through developing and implementing sustainable use of resources could integrate both conservation and development.

At last, it has to be realized that populations of $M$. nigra in Bacan Island may be genetically different from the one in mainland of Sulawesi. Hence, it is important to keep in mind that the conservation of mainland $M$. nigra is totally necessary to prevent this species from declining to extinction. 


\section{REFERENCES}

Alvard, M. 2000. The impact of traditional subsistence hunting and trapping on prey populations: Data from Wana horticulturalist of Upland Central Sulawesi in Hunting for sustainability in tropical forest edited by Robinson, J. G., Bennett, E. L. Columbia University Press, New York.

Biro Pusat Statistik (BPS). 2004. Jumlah Penduduk: Penduduk dirinci menurut kabupaten/kota di Sulawesi Utara 1980-2002. Available online: http://www.sulut.bps.go.id/ Access date: 15/03/2004

Bynum, E., Kohlkass, A. K., Pramono, A. H. 1999. Conservation status of Sulawesi Macaques. Tropical Biodiversity Vol. 6 (1\&2), pp. 123-144.

Clayton, L., Milner-Guland, E. J. 2000. The trade in wildlife in North Sulawesi, Indonesia in Hunting for sustainability in tropical forest edited by Robinson, J. G., Bennett, E. L. Columbia University Press, New York.

Deptan (Departemen Pertahanan). 2004. Daftar Undang-undang (Undang-undang No. 5 tahun 1990 tentang Konservasi Sumberdaya Alam Hayati dan Ekosistemnya. Available online: http://dokumen.deptan.go.id/doc/BDD2.nsf/cbc 531355f63c30b4725666100335da1?OpenView \&Start=1\&Count $=1000 \&$ ExpandView Access date: 29/04/2004

Forest Watch Indonesia (FWI)/Global Forest Watch (GFW). 2001. Potret Keadaan Hutan Indonesia (A Potrait of Indonesian Forests). FWI, Bogor.

Froehlich, J. W., Supriatna, J., Muskita, Y. 1996. Biodiversity and the conservation biology of $M$. nigra: an anthropological view. Tropical Biodiversity Vol. 5 (3), pp. 167-184.

Hamada, Y., Watanabe, T. 1994. Macaca nigra on Bacan Island: its morphology, distribution, and present habitat. International Journal of Primatology Vol. 15 (3), pp.487-493.

Johns, A. D., Skorupa, J. P. 1987. Responses of rainforest primates to habitat disturbance: $A$ review. International Journal of Primatology Vol. 8, pp.157-191.

Kinnaird, M. F. 1997. Sulawesi Utara: Sebuah Panduan Sejarah Alam. Yayasan Pengembangan Wallacea, GEF-Biodiversity Collections Project (LIPI), Wildlife Conservation Society, Jakarta.
Kinnaird, M. F., O'Brien, T. G. 1996. Ecotourism in the Tangkoko DuaSudara Nature Reserve: opening Pandora's box? Oryx Vol. 30 (1), pp.65-73.

Kinnaird, M. F., O'Brien, T.G., Suryadi, S. 1999. The importance of Figs to Sulawesi's Imperiled Wildlife. Tropical Biodiversity Vol.6 (1\&2), pp. 5-18.

Lee, R. 1999. Market Hunting Pressures in North Sulawesi, Indonesia. Tropical Biodiversity Vol. 6 (1 \& 2), pp. 145-162.

Lee, R. 2000. The impact of subsistence hunting in North Sulawesi, Indonesia, and conservation options in Hunting for sustainability in tropical forest edited by Robinson, J. G., Bennett, E. L. Columbia University Press, New York.

Milner-Gulland, E. J., Clayton, L. 2002. The trade in babirusas and wild pigs in North Sulawesi, Indonesia. Ecological Economics Vol 42, pp. 165-183.

O'Brien, T. G., Kinnaird, M. F. 1997. Behavior, Diet and Movements of the Sulawesi black crested macaque ( $M$. nigra). International Journal of Primatology Vol. 18 (3), pp. 321351.

O'Brien, T. G., Kinnaird, M. F. 2000. Differential vulnerability of large birds and mammals to hunting in North Sulawesi, Indonesia, and the outlook for the future in Hunting for sustainability in tropical forest edited by Robinson, J. G., Bennett, E. L. Columbia University Press, New York.

Pacific Asia Travel Association (PATA) North Sulawesi. 2004. North Sulawesi Adventures Beyond the Dreams: Geography. Available at: $\quad h$ htp://www.NorthSulawesi.com/sul_info.html. Access date: 22/04/2004

Rosenbaum, B., O'Brien, T.G., Kinnaird, M. F., Supriatna, J. 1998. Population densities of Sulawesi crested black macaques (M. nigra) on Bacan and Sulawesi, Indonesia: Effects of Habitat Disturbance and Hunting. American Journal of Primatology Vol. 44, pp. 89-106.

Ross, S., Wall, G. 1999. Evaluating ecotourism: The case of North Sulawesi Indonesia. Tourism management Vol. 20, pp. 673-682.

Ross, S., Wall, G. 2001. Ecotourism: a Theoritical Framework and an Indonesian Application in 
Tourism, Recreation and Sustainability edited by S. F. McCool and R. N. Moisey. CAB International.

Waldman, P. 2004. Brains, Served Fresh and Raw.

Available online: http://www.mad-

cow.org/260ct98 news.htm/\#bbb Access

date:03/03/2004.

Diterima : 30 April 2006

\section{Risma Illa Maulany}

Lab. Biologi Konservasi dan Dendrologi Jurusan Kehutanan, Universitas Hasanuddin

Kampus Tamalanrea, Jl. Perintis Kemerdekaan Km. 10, Makassar 90245

Telp./Fax. 0411-585917. Indonesia
Young, T. R. 2002. Sharpening CITES' teeth. World Conservation Vol.3., pp. 9-10. Available online: http://www.lucn.org/ bookstore/bulletin/3-2002/CITES-GB-30-31 Access date: 14/03/2003. 